\title{
Projekt zmian z dnia 28 listopada 2017 roku w postępowaniu cywilnym
}

\section{The draft of amendments dated 28th of November 2017 in civil proceedings}

\section{mgr Anna Sadkowska}

E-mail: sadkowska1@o2.pl; nr orcid: 0000-0002-6405-912x

\begin{abstract}
Streszczenie
Niniejsza publikacja dotyczy proponowanych przez Ministerstwo Sprawiedliwości zmian, które mają usprawnić i przyśpieszyć postępowanie cywilne. Projekt przewiduje zmiany w Kodeksie postępowania cywilnego, ustawie o księgach wieczystych i hipotece, ustawie o kosztach sądowych w sprawach cywilnych, ustawie prawo o ustroju sądów powszechnych, ustawie o komornikach sądowych i egzekucji, ustawie o dochodzeniu roszczeń grupowych.

Najistotniejsze zmiany dotyczą postępowania cywilnego. Projekt wprowadza nowe instytucje i nowe uprawnienia dla stron oraz przywraca odrębne postępowanie gospodarcze. Ponadto założeniem zmian jest także uczynienie stron współodpowiedzialnymi za wynik procesu. Projekt jest na etapie konsultacji i nie wiadomo jaki będzie rezultat prac legislacyjnych.
\end{abstract}

Słowa kluczowe: projekt, postępowanie cywilne, postępowanie przygotowawcze, rozprawa, prekluzja dowodowa.

\section{Summary}

This publication is regarding changes proposed by the Ministry of Justice which they are supposed to streamline and to precipitate the civil procedure. The draft is anticipating amendments to the Code of Civil Procedure, the act on the land register and the mortgage, the act on court fees in civil cases, for act law on the system of courts of general jurisdiction, the act on bailiffs and the execution, the act on pursuing claims group.

Substantial changes concern the civil procedure. The draft is introducing new institutions and new entitlements for sides as well as is restoring separate economic proceedings. Moreover also making sides is assuming changes jointly responsible behind the outcome of the process.

The draft is on the consultation phase and it isn't known what result of legislative works will be.

Key words: draft, civil procedure, preparatory proceedings, trial, evidence limitation.

JEL: K15

Str. 46-51 